\title{
わが国沿岸の波エネルギー賦存量と平均波高，平均周期の頻度分布

\author{
Estimation of Existing Wave Power of Japanese Coast, and Frequency \\ Distribution of Mean Wave Height and Mean Wave Period
}

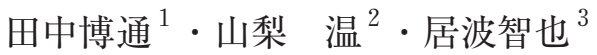

\author{
Hiromichi TANAKA, On YAMANASHI and Tomoya INAMI
}

\begin{abstract}
When developing wave power generation, in order to calculate electric power from the existing wave power and wave energy of the Japanese coast, it is important to grasp the characteristic of a wave. This research has grasped the amount of annual wave energy of the Japanese coast based on the annual data of the Nationwide Ocean Wave Information Network for Ports and Harbors (NOWPHAS). Moreover, frequency distribution of the average wave quantity for 20 minutes of NOWPHAS and an average periods is created, comparison with distribution of the past, such as Rayleigh distribution, is performed, and the concept of still newer frequency distribution is proposed.
\end{abstract}

\section{1. はじめに}

日本沿岸の波エネルギーの賦存量は，全国平均で $6 \mathrm{MW} / \mathrm{m}$ と推測されているが（高橋・安達，1986）, この 波エネルギーはわが国においてほとんど利活用されてい ないのが現状である。わが国における波力発電は, 1977 年から世界に先駆けて実験船「海明」（益田，1987）で 実証試験が行われ，その後数々の実証試験が行われたが (田中，2009a），いまだ実用化に至っていない。一方， 欧米諸国においては2000年以降，欧州委員会の地球温暖 化対策としての再生可能エネルギー利用を基本においた 政策に支えられ，様々なタイプの波力発電が開発されて いる（田中，2009a）。わが国でも，エネルギー基本計画 と海洋基本法の見直しの中で海洋エネルギーの研究開発 と実用化が推進されている.

波力発電は，波エネルギーを電気エネルギーに変換す る方式から 8 種類に大別されるが (EMEC), 著者が現在 開発しているタイプは越波式に属する（田中ら，2009b; 田中，2013）。越波式波力発電の原理は，図-1に示すよ うに波が斜面を遡上することにより波エネルギーが位置 エネルギーに変換され，貯水槽水位と周囲海域の水位差 によって生じる流水エネルルギーをプロペラが受けるト ルクにより発電機で発電する方式である. したがって, 設置海域の波エネルギー賦存量を把握した上で，いかに 多くの越波量を得るかが最も重要な要素となる．現在開 発している越波式波力発電装置は，波高頻度分布を考慮 した多段式である。よって, 設置地点の年間の波高と周 期の頻度分布を推定することが必要となる。

本研究では，全国港湾波浪情報網（NOWPHAS）の年

$\begin{array}{llll}1 & \text { 正会員 } & \text { 工博 } & \text { 東海大学教授海洋学部環境社会学科 } \\ 2 \text { 学生会員 } & \text { 修(工) } & \text { 東海大学大学院海洋学研究科海洋工学専攻 } \\ 3 & \text { 修(工) } & \text { 東海大学特定研究員 }\end{array}$

間データを基にわが国沿岸の年間波エネルギー賦存量を 把握し, 発電効率を仮定して発電量の試算をするととも に, NOWPHASの 20 分間の平均波高と平均周期の頻度分 布を作成し, Rayleigh分布などの既往の分布との比較を 行い, さらに新たな頻度分布の概念を提案することを目 的とした. 発電装置設置地点の波浪特性を把握すること によって，その地点における波エネルギーを活かす越波 式波力発電装置の形状を定められることから各地の波エ ネルギーの算出は有用である。 また, 波高と周期の頻度 分布は, 海洋波浪に関する研究の黎明期にLonguetHiggins (1952), Puts (1952), Bretschneider (1959) ら により実測值を基に研究され，多くの知見が得られてい るが，越波式波力発電装置を設計するために，より観測 データに即した簡便な頻度分布が必要となることから今 回の研究を行った.

\section{2. わが国沿岸の波エネルギー賦存量}

\section{（1）年間波エネルギーの求め方}

全国の波エネルギーの算定は，全国に63箇所の波浪観 測所を有する全国港湾波浪情報網（NOWPHAS）の 2008 年観測データのうち，欠損データの少ない61箇所につい て算定した. NOWPHASの公開している波高・周期別出 現頻度統計は 2 時間ごとの観測データである．2時間ごと

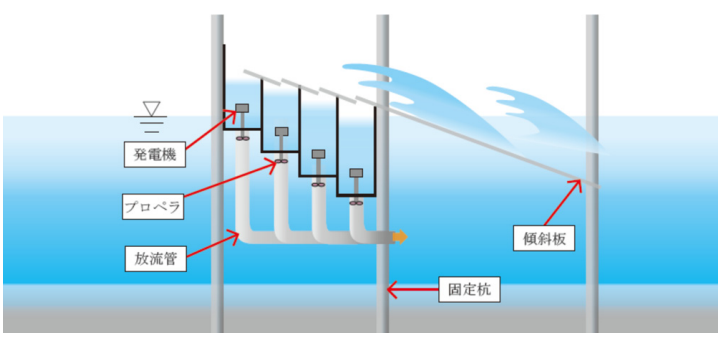

図-1 越波式波力発電の概要図 
の有義波高 $\left(H_{1 / 3}\right)$ と有義波周期 $\left(T_{1 / 3}\right)$ を用いて Bretschneider-光易スペクトルから求められる不規則波の 波エネルギー式である次式から単位幅当たりの波パワー $\left(P_{w}\right)$ を求めた.

$$
P_{w}=0.441 H_{1 / 3}^{2} T_{1 / 3} \quad(\mathrm{~kW} / \mathrm{m})
$$

なお，波高・周期別出現頻度統計は，デー夕収録間隔が 2 時間ごと, 波高階級は $2.0 \mathrm{~m}$ まで $0.25 \mathrm{~m}$ 間隔で $2 \mathrm{~m}$ 以上は $0.5 \mathrm{~m}$ 間隔，周期間隔は $2 \mathrm{~s}$ ごとになっている．各階級での 平均有義波高 $\left(H_{1 / 3}\right)$ は階級の中間值とし，その階級の 有義波高に対する平均有義波周期 $\left(T_{1 / 3}\right)$ は, 各階級の中 心周期にその周期階級のデー夕数を掛けて総和をとり, 波高階級のデー夕総数で割ることで重みを考慮した平均 有義波周期とした。また，求めた各波高階級の平均有義 波高と平均有義周期から式（1）よりその階級の波エネ ルギーを算定し，その波高階級の総波デー夕数を掛ける ことで各波高階級の波エネルギーとし，同様の計算を各 階級で行い，その総和が表-1 に示す観測地点のデー夕総 数よる年間波エネルギーである. 観測デー夕に欠損があ ることから，デー夕取得率を考慮するために総波エネル ギーをデー夕総数で除した 1 デー夕当たりの波エネルギ 一に24時間と366日を掛けて年間波パワーを求めた。こ の值が，表-1に示す年間波エネルギーである.

\section{（2）わが国沿岸の年間波エネルギー賦存量分布}

日本各地における年間波エネルギー賦存量を図-2に示 す。今回算定した年間波エネルギーについて，地方ごと の特徵について述べる。

北海道地方の全ての観測所において，年間波エネルギ 一量が $20,000 \mathrm{kWh} / \mathrm{m}$ 以上である。中でも日本海に面する 瀬棚観測所は $60,000 \mathrm{kWh} / \mathrm{m}$ を超えていた．東北地方では， ほぼ全ての観測所の年間波エネルギー量が $30,000 \mathrm{kWh} / \mathrm{m}$ を超え，日本海側では $40,000 \mathrm{kWh} / \mathrm{m}$ を超える観測所が多 い. 中でも深浦, 酒田観測所は $80,000 \mathrm{kWh} / \mathrm{m}$ を超える. なお, 青森観測所は内湾であるため $1500 \mathrm{kWh} / \mathrm{m}$ と小さい. 関東地方は，常陸那珂観測所および波浮観測所の年間波 エネルギー量は $70,000 \mathrm{kWh} / \mathrm{m}$ を超えている。なお，アシ 力島観測所および第二海堡観測所の值は $10,000 \mathrm{kWh} / \mathrm{m}$ 以 下であった。中部地方の日本海側では, 年間波エネルギ 一量が $50,000 \mathrm{kWh} / \mathrm{m}$ を超える観測所が多くみられる。た だし，内湾の伏木富山観測所および敦賀観測所は $10,000 \mathrm{kWh} / \mathrm{m}$ 以下であった。太平洋側では下田観測所お よび御前崎観測所は $18,000 \mathrm{kWh} / \mathrm{m}$ を超えている。なお， 清水観測所は $10,000 \mathrm{kWh} / \mathrm{m}$ 以下であった。近畿地方の日 本海側の柴山観測所に㧍ける年間波エネルギー量は 60,000 kWh $/ \mathrm{m}$ を超えているが，港内に設置された柴山港 内観測所は $10,000 \mathrm{kWh} / \mathrm{m}$ 以下であった。太平洋側の潮岬 観測所は $30,000 \mathrm{kWh} / \mathrm{m}$ を超えている。なお，内湾の伊勢 湾観測所および神戸観測所は $10,000 \mathrm{kWh} / \mathrm{m}$ 以下であっ 表-1＼cjkstart観測值と年間波エネルギー（2008年）

\begin{tabular}{|c|c|c|c|c|c|c|c|c|}
\hline 地名 & \begin{tabular}{|c|} 
年間有義 \\
波高 \\
(m)
\end{tabular} & $\left|\begin{array}{c}\text { 年間有義 } \\
\text { 波周期 } \\
(\mathrm{s})\end{array}\right|$ & $\begin{array}{c}\vec{F}^{\prime}-夕 \\
\text { 数 }\end{array}$ & $\begin{array}{c}\text { 欠测 }=7- \\
\text { 夕数 }\end{array}$ & 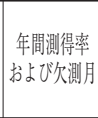 & 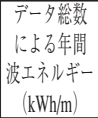 & 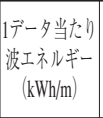 & $\begin{array}{l}\text { 年間波工 } \\
\text { ネルギー } \\
(\mathrm{kWh} / \mathrm{m})\end{array}$ \\
\hline 留萌 & 0.98 & 5.3 & 4340 & 52 & $98.8 \%$ & 51,452 & 5.93 & 52,068 \\
\hline 石驸新港 & 0.81 & 4.6 & 4337 & 55 & $98.7 \%$ & 31,396 & 3.62 & 31,794 \\
\hline 瀬棚 & 1.07 & 5.6 & 4329 & 63 & $98.6 \%$ & 61,086 & 7.06 & 61,975 \\
\hline 青森 & 0.30 & 3.7 & 4355 & 37 & $99.2 \%$ & 1,526 & 0.18 & 1,539 \\
\hline 深浦 & 1.16 & 5.7 & 4378 & 14 & $99.7 \%$ & 79,912 & 9.13 & 80,168 \\
\hline 秋田 & 0.86 & 5.2 & 3515 & 877 & $\begin{array}{r}80.0 \% \\
\text { 1 2月矢澌 }\end{array}$ & 43,824 & 5.44 & 47,786 \\
\hline 酒田 & 1.17 & 5.8 & 4387 & 5 & $99.9 \%$ & 85,668 & 9.76 & 85,766 \\
\hline 新渴沖 & 0.96 & 5.4 & 3989 & 403 & $90.8 \%$ & 44,862 & 5.62 & 49,394 \\
\hline 直江津 & 0.95 & 5.4 & 4304 & 88 & $98.0 \%$ & 50,388 & 5.85 & 51,418 \\
\hline 富山 & 0.49 & 5.0 & 4391 & 1 & $100.0 \%$ & 20,100 & 2.29 & 20,105 \\
\hline 伏楅山 & 0.40 & 5.0 & 4009 & 383 & $91.3 \%$ & 7,004 & 0.87 & 7,673 \\
\hline 輪島 & 1.15 & 5.8 & 4267 & 125 & $97.2 \%$ & 68,386 & 8.01 & 70,389 \\
\hline 金讯 & 1.07 & 5.7 & 4285 & 107 & $97.6 \%$ & 60,954 & 7.11 & 62,476 \\
\hline 福井 & 1.06 & 5.9 & 4383 & 9 & $99.8 \%$ & 60,746 & 6.93 & 60,871 \\
\hline 敦賀 & 0.22 & 5.1 & 4352 & 40 & $99.1 \%$ & 1,470 & 0.17 & 1,484 \\
\hline 柴山 & 1.08 & 6.0 & 4292 & 100 & $97.7 \%$ & 60,652 & 7.07 & 62,065 \\
\hline 柴山港内 & 0.34 & 5.8 & 4392 & 0 & $100.0 \%$ & 4,788 & 0.55 & 4,788 \\
\hline 鳥取 & 1.04 & 5.9 & 2418 & 1974 & $\begin{array}{l}55.10 \% \\
8 \sim 12 月\end{array}$ & 30,120 & 6.23 & 54,709 \\
\hline 境港 & 0.36 & 4.6 & 4145 & 247 & $94.4 \%$ & 3,328 & 0.40 & 3,526 \\
\hline 浜田 & 1.08 & 5.9 & 4389 & 3 & $99.9 \%$ & 52,590 & 5.99 & 52,626 \\
\hline 藍島 & 0.62 & 4.7 & 4379 & 13 & $99.7 \%$ & 12,650 & 1.44 & 12,688 \\
\hline 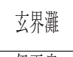 & 0.92 & 5.4 & 3904 & 488 & $\begin{array}{r}88.9 \% \\
12 \text { 月欠測 }\end{array}$ & 29,486 & 3.78 & 33,172 \\
\hline 伊王島 & 0.56 & 5.3 & 4278 & 114 & $97.4 \%$ & 10,448 & 1.22 & 10,726 \\
\hline 熊本 & 0.15 & 3.7 & 4383 & 9 & $99.8 \%$ & 478 & 0.05 & 479 \\
\hline 名頼 & 1.14 & 6.6 & 4387 & 5 & $99.9 \%$ & 57,646 & 6.57 & 57,712 \\
\hline 那覇 & 0.95 & 6.4 & 4356 & 36 & $99.2 \%$ & 42,078 & 4.83 & 42,426 \\
\hline 紋別 (南) & 0.73 & 5.9 & 3934 & 458 & $89.6 \%$ & 25,224 & 3.21 & 28,161 \\
\hline 釗路 & 0.98 & 7.1 & 4374 & 18 & $99.6 \%$ & 34,976 & 4.00 & 35,120 \\
\hline 十勝 & 0.94 & 7.5 & 4361 & 31 & $99.3 \%$ & 37,182 & 4.26 & 37,446 \\
\hline 苦小牧 & 0.73 & 6.9 & 4343 & 49 & $98.9 \%$ & 21,030 & 2.42 & 21,267 \\
\hline むつ小川原 & 1.09 & 7.6 & 4384 & 8 & $99.8 \%$ & 52,244 & 5.96 & 52,339 \\
\hline 分 & 0.97 & 7.4 & 4391 & 1 & $100.0 \%$ & 42,826 & 4.88 & 42,836 \\
\hline 久慈 & 1.22 & 7.8 & 4101 & 291 & $93.4 \%$ & 59,908 & 7.30 & 64,159 \\
\hline 宮古 & 0.55 & 6.9 & 4344 & 48 & $98.9 \%$ & 11,740 & 1.35 & 11,870 \\
\hline 釡石 & 0.90 & 7.8 & 4085 & 307 & $93.0 \%$ & 35,328 & 4.32 & 37,983 \\
\hline 石巻 & 0.64 & 6.9 & 4390 & 2 & $100.0 \%$ & 14,150 & 1.61 & 14,156 \\
\hline 仙台新港 & 0.79 & 8.3 & 4390 & 2 & $100.0 \%$ & 28,404 & 3.24 & 28,417 \\
\hline 相馬 & 1.00 & 8.5 & 4388 & 4 & $99.9 \%$ & 46,766 & 5.33 & 46,809 \\
\hline 小名浜 & 1.13 & 8.0 & 4359 & 33 & $99.2 \%$ & 56,720 & 6.51 & 57,149 \\
\hline 常陸那珂 & 1.32 & 7.7 & 4111 & 281 & $93.6 \%$ & 69,422 & 8.44 & 74,167 \\
\hline 鹿島 & 1.24 & 7.0 & 100 & 4292 & $\begin{array}{r}2.28 \% \\
2 \sim 12 \text { 月欠测 }\end{array}$ & 1,098 & 5.49 & 48,224 \\
\hline 第二海堡 & 0.38 & 3.6 & 4365 & 27 & $99.4 \%$ & 2,446 & 0.28 & 2,461 \\
\hline アシカ島 & 0.46 & 4.5 & 4354 & 38 & $99.1 \%$ & 4,786 & 0.55 & 4,828 \\
\hline 波浮 & 1.43 & 7.3 & 4364 & 28 & $99.4 \%$ & 77,024 & 8.82 & 77,518 \\
\hline 下田 & 0.85 & 7.2 & 3225 & 1167 & $73.4 \%$ & 20,946 & 3.25 & 28,526 \\
\hline 清水 & 0.41 & 6.0 & 4281 & 111 & $97.5 \%$ & 5,088 & 0.59 & 5,220 \\
\hline 御前崎 & 0.80 & 6.2 & 3951 & 441 & $90.0 \%$ & 17,121 & 2.17 & 19,032 \\
\hline 伊勢湾 & 0.31 & 3.7 & 4391 & 1 & $100.0 \%$ & 1,326 & 0.15 & 1,326 \\
\hline 潮翔 & 1.03 & 7.3 & 4382 & 10 & $99.8 \%$ & 38,510 & 4.39 & 38,598 \\
\hline 神戸 & 0.28 & 3.4 & 4391 & 1 & $100.0 \%$ & 1,232 & 0.14 & 1,232 \\
\hline 小松島 & 0.36 & 5.0 & 3703 & 689 & $\begin{array}{l}84.31 \% \\
\text { 2月欠测 }\end{array}$ & 2,600 & 0.35 & 3,084 \\
\hline 室津 & 0.66 & 6.8 & 4385 & 7 & $99.8 \%$ & 16,224 & 1.85 & 16,250 \\
\hline 高知 & 0.62 & 7.2 & 4342 & 50 & $98.9 \%$ & 15,152 & 1.74 & 15,326 \\
\hline 上川口 & 0.61 & 7.7 & 4389 & 3 & $99.9 \%$ & 16,108 & 1.84 & 16,119 \\
\hline 荻田 & 0.28 & 3.0 & 4372 & 20 & $99.5 \%$ & 1,056 & 0.12 & 1,061 \\
\hline 緗島 & 0.93 & 7.3 & 4284 & 108 & $97.5 \%$ & 37,058 & 4.33 & 37,992 \\
\hline 志布志湾 & 0.53 & 6.8 & 4210 & 182 & $95.9 \%$ & 9,140 & 1.09 & 9,535 \\
\hline 鹿児島 & 0.16 & 3.5 & 3744 & 648 & $\begin{array}{l}85.25 \% \\
\text { 2月膹 }\end{array}$ & 54 & 0.01 & 63 \\
\hline 中域浮 & 0.99 & 7.3 & 4378 & 14 & $99.7 \%$ & 36,668 & 4.19 & 36,785 \\
\hline 平良沖 & 0.65 & 6.0 & 1545 & 2847 & $\begin{array}{r}35.18 \% \\
7 \sim 12 \text { 月欠䁚 }\end{array}$ & 6,442 & 2.08 & 18,313 \\
\hline 石坦沖 & 0.43 & 5.0 & 3623 & 769 & $\begin{array}{l}82.49 \% \\
\text { 8月欠測 }\end{array}$ & 5,056 & 0.70 & 6,129 \\
\hline
\end{tabular}




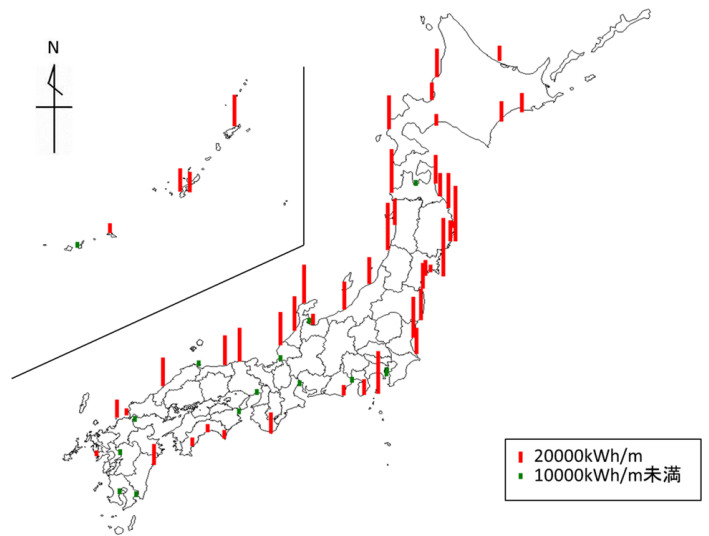

図-2 日本全国の年間波エネルギー量

た。中国地方では，鳥取観測所および浜田観測所におけ る年間波エネルギー量は $5,0000 \mathrm{kWh} / \mathrm{m}$ を超えている。な お，境港観測所は $10,000 \mathrm{kWh} / \mathrm{m}$ 以下であった。四国地方 の多くの観測所の年間波エネルギー量が $15,000 \mathrm{kWh} / \mathrm{m}$ 以 上であったが，小松島観測所は $10,000 \mathrm{kWh} / \mathrm{m}$ 以下であっ た。 九州地方の日本海側の玄界灘観測所における年間波 エネルギー量は $30,000 \mathrm{kWh} / \mathrm{m}$ を超えているが，藍島観測 および伊王島観測所では $15,000 \mathrm{kWh} / \mathrm{m}$ 以下であった。太 平洋側では細島観測所のみ $35,000 \mathrm{kWh} / \mathrm{m}$ を超えている. そのほかの観測所は $10,000 \mathrm{kWh} / \mathrm{m}$ 以下であった。沖縄・ 奄美地方では，石垣沖観測所における年間波エネルギー 量は $10,000 \mathrm{kWh} / \mathrm{m}$ 以下であったが，それ以外の観測所は 20,000kWh/m 以上であった.

総じて日本海側の観測所において波エネルギーが大き い地点が多くみられる。また, 東北地方では日本海側, 太平洋側とも波エネルギー賦存量は多く，日本海側の年 間波エネルギー量の平均は $71,240 \mathrm{kWh} / \mathrm{m}$ であり，太平洋 側では $37,321 \mathrm{kWh} / \mathrm{m}$ であった。

\section{（3）年間波エネルギー賦存量の推移}

各観測所における2001～2010年までの年間波エネル ギー量の推移を示した一例を図-3に示す。波エネルギー 量は式（1）に示すように有義波高の2乗と有義波周期の 積によって計算するため，突出した年間波エネルギー量 が生じた年は，台風等気象変化による高波高，長周期の 波の発生に起因していると考えられるが，それらの波を 考慮すれば波エネルギーには地域性があるものの長期に わたってはほぼ一定であると言える。しかし，釜石観測 所における2004年の年間波エネルギー量の低下は，波高 階級 $100 \mathrm{~cm}$ 以下の波が出現する割合は2004年では $84 \%$, 2005 年には $69 \%$ と差があり，波高階級 101 200cmの波が

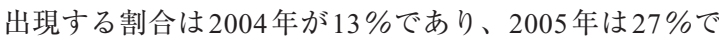
ある。このような差が年間波エネルギー量の差に起因し ていると考えられる.

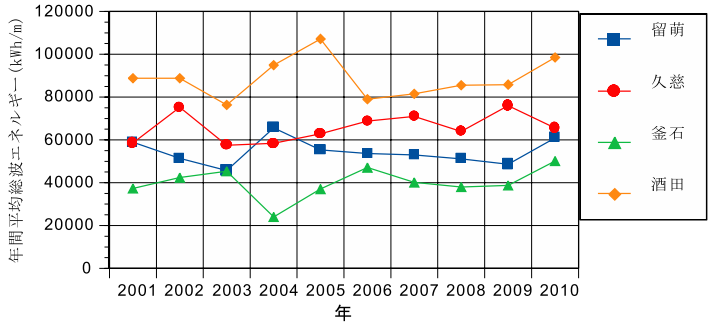

図-3 北海道・東北地方の年間波エネルギー量の推移

波力発電を設置する際に必要となる条件は，構造的に 安全であること, 発電コスト, 安定して電力が得られる ことである. 構造的な問題は既往の海洋構造物建設の技 術があり，建設コストはおもに建設費と維持管理費に関 係する。図-3より，年間を通してほぼ一定の波エネルギ 一が期待できることから，ほぼ一定の電力が得られるも のと考えられる。図-3より，酒田の年間波エネルギーを 約 $90,000 \mathrm{kWh} / \mathrm{m}$ とし, 稼働率 $95 \%$, 発電効率 $15 \%$ と仮定 すると年間 $12,825 \mathrm{kWh} / \mathrm{m}$ の電力が得られることがわかる.

\section{3. 平均波高, 平均周期の頻度分布}

著者ら（田中，2010）は，不規則波の場合，斜面板の 勾配が $20^{\circ}$ の時が最も高く波が打ちあがることを示した (田中，2010)。また，越波量も斜面板の勾配が $20^{\circ}$ の時 が最も多く得られることを示した（田中，2013）。多段 型越波式波力発電装置の越波量を推定するためには，設 置地点の波高と周期の頻度分布を知ることが重要であ る.そこで，2005年〜2010年の 20 分ごとのNOWPHAS デー夕の平均波高 $(H)$ と平均周期 $(T)$ の頻度分布を 12 観測所について作成し，それぞれの頻度分布関数につい て考察した。一般的に, 波高, 周期の頻度分布の研究は, 生の波形デー夕を対象とするものであるが，ここでは越 波式波力発電の越波量を推定することを目的とすること から，20分ごとの平均波高と平均周期に関する頻度分布 について考察することは意義あるものと考える.

\section{（1）平均波高の頻度分布}

20 分ごとの平均波高 $(H)$ と年間平均波高 $\left(H_{\mathrm{m}}\right)$ の波 高比 $\left(H / H_{\mathrm{m}}\right)$ の区切りを 0.25 とし，それぞれの区切り間 のデータ数を求めて頻度分布を作成した. Longuet-Higgins （1952）は，海洋波の波高の頻度分布を式（2）に示す一 般的な Rayleigh分布とした。

$$
p\left(\frac{H}{H_{m}}\right)=\frac{\pi}{2} \frac{H}{H_{m}} \exp \left\{-\frac{\pi}{4}\left(\frac{H}{H_{m}}\right)^{2}\right\}
$$

図-4に示す御前崎観測所（2006年）の実測值の頻度分 布と式（2）を比較すると，最も重要なピーク值に差が 生じた。分布形状の傾向は良いものと考えられるので, 波高の頻度分布はRayleigh分布として，分布の係数につ いて以下考察する。 


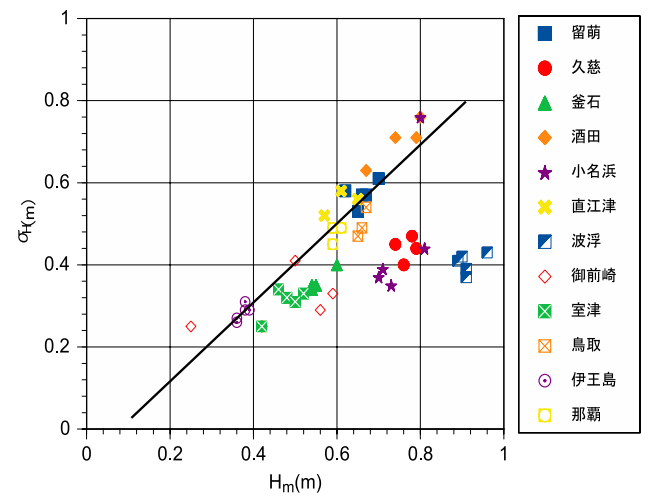

図-4 年間平均波高 $\left(H_{\mathrm{m}}\right)$ と標準偏差 $(\sigma)$ との関係

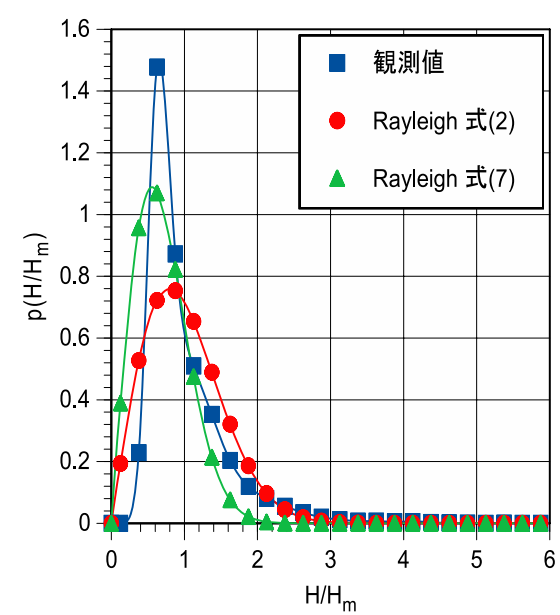

図-5 p $\left(H / H_{\mathrm{m}}\right)$ の分布と Rayleigh 分布（御前崎 2006年）

不規則現象の確率密度関数は，ほぼ平均值を中心とし た対称または非対称の関数形となり, 統計量の標準偏差 $(\sigma)$ と分布のモーメント $\left(\mathrm{m}_{\mathrm{i}}\right)$ の值により歪んだ関数形 状となる。ここでは，標準偏差に着目して，20分ごとの 平均波高の頻度分布を求めることとする.

12 観測所の年間平均波高と標準偏差を図-4に示す。こ の図より, 年間平均波高が大きくなれば標準偏差も大き くなる傾向があることが分かる. 久慈, 小名浜と波浮観 測所だけ他の9観測所と異なる傾向となった。図-4に久 慈，小名浜と波浮観測所を除いて求めた式（3）で表さ れる関係式を併記した。

$$
\sigma=1.030 H_{m}-0.138
$$

また，連続観測した 100 波前後の海洋波浪から求めた Putz (1952), Longuet-Higgins (1952), Bretschneider （1959）の平均波高と標準偏差の関係式を $\mathrm{m}$ 単位に換算 した式は,

それぞれ式 (4)，式（5），式（6）である.

$$
\sigma=1.621 H_{m}+0.394
$$

$\sigma=1.716 H_{m}$

$$
\sigma=1.716 H_{m}
$$

当然ながら, 連続観測した海洋波の統計量と 20 分ごと の平均波高を基に処理した統計量では傾向が異なるが, 図-4に示す関係から, 年間平均波高と平均波高の標準偏 差は関係があることが分かる。

そこで，年間平均波高と標準偏差の比を係数とした式 （7）を用いて観測值の頻度分布と比較検討した.

$$
p\left(\frac{H}{H_{m}}\right)=\left(\frac{H_{m}}{\sigma}\right)^{2} \frac{H}{H_{m}} \exp \left\{-\frac{1}{2}\left(\frac{H_{m}}{\sigma}\right)^{2}\left(\frac{H}{H_{m}}\right)^{2}\right\} \cdots \text { (7) }
$$

図-5は，2006年の御前崎観測所の平均波高を年間平均 波高の比で無次元化したときの頻度分布である.この図 には式（2）と式（7）で算定したRayleigh分布を示して ある. ピーク值は異なるが, 式（7）は比較的観測值と 一致している. 他の観測所の平均波高の頻度分布も式 （7）から求めた分布とよく一致した.

\section{(2) 平均周期の頻度分布}

20 分ごとの平均周期 $(T)$ と年間平均周期 $\left(T_{\mathrm{m}}\right)$ の周 期比 $\left(T / T_{\mathrm{m}}\right)$ の区切りを 0.20 とし，それぞれの区切り間 のデー夕数を求めて頻度分布を作成した。平均周期の頻 度分布を検討する前に, 年間平均周期と標準偏差 $(\sigma)$ との関係について論じることとする.

12 観測所の年間平均周期と標準偏差を図-6に示す。こ の図より，年間平均周期と標準偏差との間には明確な関 係がないことがわかる。

海洋波の周期の頻度分布に関する研究として, Bretschneider（1959）は式（8）を, 岩垣ら（1975）は Weibull分布である式（9）を提案した. 式（8）は4次の Weibull分布である。岩坦らの研究では, 周期の平均值 $\left(T_{\mathrm{m}}\right)$ でなく周期の標準偏差を用いている.

$$
\begin{aligned}
& p\left(\frac{T}{T_{m}}\right)=2.7\left(\frac{T}{T_{m}}\right)^{3} \exp \left\{-0.675\left(\frac{T}{T_{m}}\right)^{4}\right\} \\
& p\left(\frac{T}{T_{m}}\right)=\beta \mathrm{m}\left(\frac{T}{T_{m}}\right)^{\mathrm{m}-1} \exp \left\{-\beta\left(\frac{T}{T_{m}}\right)^{\mathrm{m}}\right\}
\end{aligned}
$$

図-7にWeibull分布の形状母数 $(\mathrm{m})$ を $\mathrm{m}=2 \sim 6$ まで 変化させて計算した分布を併記した。この図から， $\mathrm{m}=$ 5 の分布は観測值のピーク值とよく一致するが，頻度分 布全体では $\mathrm{m}=4$ の場合が観測值の頻度分布と一致する. この時の相関係数は 0.955 であった. 今回は, 12 観測所 の $2005 \sim 2010$ 年の 20 分ごとの平均周期の頻度分布が, 図-7に示すように既知であることから，観測值の頻度分 布のピーク值となる $\left(T / T_{\mathrm{m}}\right) \mathrm{p}$ と $\beta$ との関係式 $(10)$ より $\beta$ を求めた。

$$
\beta=\frac{m-1}{m} \frac{1}{\left(T / T_{m}\right)_{p}^{m}}
$$

観測值の頻度分布のピーク值から式（10）より $\beta$ を求 めたところ, 留萌観測所の 2009 年の $\beta$ 值を除き, 年ごと 


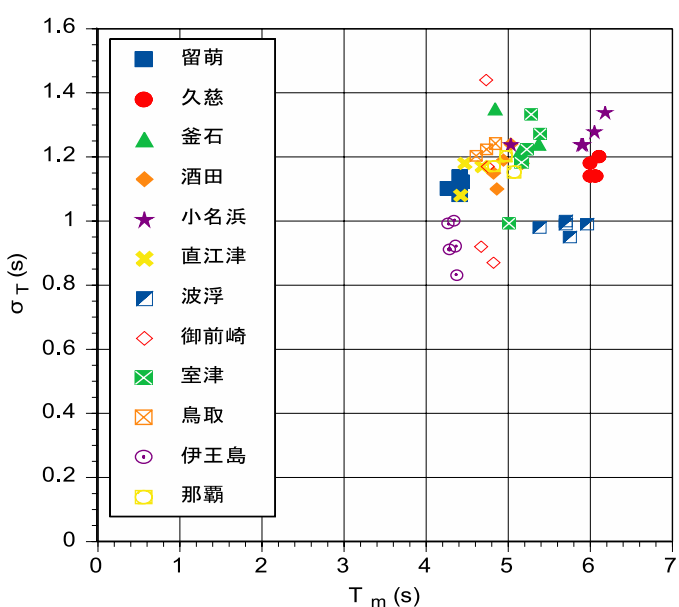

図-6 年間平均周期 $\left(T_{\mathrm{m}}\right)$ と標準偏差 $(\sigma)$ との関係

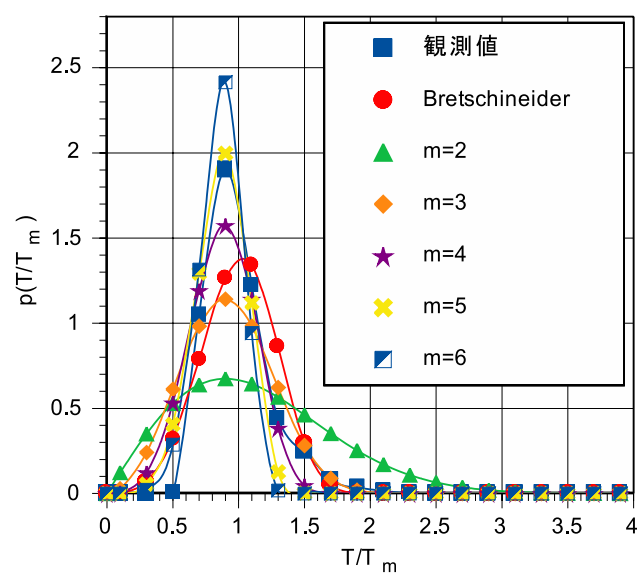

図-7 $\mathrm{p}\left(T / T_{\mathrm{m}}\right)$ の分布とBretschniderの分布, Weibull分布比の 較（御前崎2006年）

の観測所の $\beta$ 值にそれほどの差異はなかった.すなわち, 各観測所の $\beta$ 值はほぼ一定であるとみなすことができる. 図-8にWeibull分布の周期の標準偏差 $\left(\sigma_{\mathrm{T}}\right)$ と年間平均 周期 $\left(T_{\mathrm{m}}\right)$ との比と $\beta$ との関係を示す. 図より $\beta$ は一定 でなく， $\sigma_{\mathrm{T}} / T_{\mathrm{m}}$ に関係することがわかる. その関係式は, 式（11）となる.

$$
\beta=2.94 \sigma_{T} / T_{m}+0.406
$$

\section{4. 結論}

以下に主要な結論を述べる.

1）NOWPHASの波浪観測データを基に61 地点の年間波 エネルギー量を算定した結果，東北地方の年間波エネル ギーが30,000kW/mを超え，特に日本海側では $40,000 \mathrm{~kW} / \mathrm{m}$ を超える観測所がある。稼働率 $(95 \%)$ ，発電効率 $(15 \%)$ として年間発電量を求めると酒田では $12,800 \mathrm{~kW} / \mathrm{m}$

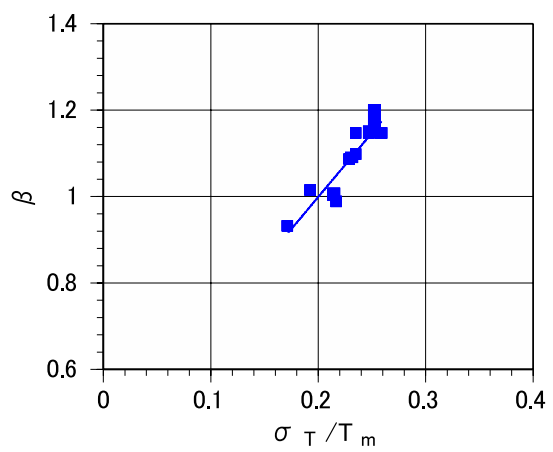

図-8 Weibull分布の $\beta$ と $\sigma_{\mathrm{T}} / T_{\mathrm{m}}$ の関係

となる.

2）波高の頻度分布は，標準偏差を考慮したRayleigh分布 （式（7））で表すことができる.

3）周期の頻度分布は，Weibull分布（式（9））の4次が 観測值と一致する。 また, 各観測所の $\beta$ は一定值でなく, $\sigma_{\mathrm{T}} / T_{\mathrm{m}}$ に関係する式（11）で求めることができる.

謝辞：本研究は，科学研究費補助金（基盤研究（B））と 独立行政法人 新エネルギー・産業技術総合開発機構 （NEDO）の「海洋エネルギー技術研究開発」による成果 であることを付記し，ここに謝意を表する。

\section{参 考 文 献}

岩坦雄一・木村 晃（1975）：不規則波浪の周期の確率特性に 関する研究, 第22回海岸工学講演会論文集, pp.295-300. 高橋重雄・安達 崇 (1989)：日本周辺の波パワーとその利用 に関する一考察，第36回海講論文集，pp.874-878.

田中博通・鈴木厚志・淀川已之助 (2009a)：波力発電の現状 と重力式（越波型）波力発電装置の開発，海洋開発論文 集, 第 25 巻, pp.359-364.

田中博通・鈴木厚志・淀川已之助 $(2009 \mathrm{~b})$ ：沿岸 5 地点の波工 ネルギー賦存量と越波型波力発電装置の開発，第 21 回海 洋工学シンポジウム講演論文集, 日本海洋工学会, pp.1-6. 田中博通・淀川已之助・鈴木厚志 (2010) : 越波型波力発電装 置開発に向けた波の打上げ特性に関する研究，土木学会 論文集B2（海岸工学），Vol.66, No.2, pp.1271-1275.

田中博通（2013）: 波力発電の現状と将来展望, 日本エネルギ 一学会誌, Vol.92, 日本エネルギー学会, pp.241-247. 益田善雄 (1987)：日本の波力発電，霞出版社.

Bretschneider, C. L. (1959): Wave Variability and Wave Spectra for Wind-generated Gravity Waves, Technical Memorandum No.118, Beach Erosion Board, Corps of Engineering, pp.1-192. EMEC : http://www.emec.org.uk/marine-energy/wave-devices/ Longuet-Higgins, M. S. (1952): On the Statistical Distribution of the Heights of Sea Wave, J. of Marine Research, Vol.11, No.3, pp. 245-266.

Putz, R. R. (1952): Statistical Distribution for Ocean Waves, Trans. American Geophysical Union,Vol.33, No.5, pp.685-692. 